\title{
Growth and Development of Companies in the Function Mergers and Acquisitions
}

\author{
ALEKSANDRA B. VIDOVIĆ, Pan-European University "Aperion" \\ College od Management Modern, Banja Luka \\ Professional paper \\ Bosnia and Herzegovina \\ UDC: $005.412: 334.7$ \\ 005.591 .45
}

DOI: 10.5937/tehnika1505866V

The author affirms the need: Acquisitions and mergers as an element of growth and development of companies. This paper provides a critical overview of contributions to the given topic. The main objective of the paper is to identify the importance of strategic aspects of mergers and acquisitions as a growth strategy and company development. These two strategies enable companies to adapt to business and achieve greater financial effects of the present conditions of business as globalization requires.

Key words: enterprise, growth, development, acquisition, merger

\section{INTRODUCTION}

According to many authors, globalization is a term that is often used in different contexts, and therefore there is a very large number of definitions:

The process of globalization today is seen by many as the process of establishing the domination of Western civilization. From there stems and resistance to globalization in many individuals and groups. Very often we meet with the thesis that globalization means Westernized, and in this case ask the question, what are the arguments for this theory? Firstly, the contemporary media based on computer technology are in English and thus did this universal language foreign, language, putting all others in the background.

Second, America and Europe dominate the global technology lead us in many technological solutions are increasingly becoming an essential element of the everyday lives of people around the world. [8]

Attempts to measure and compare Stephan globalization, national companies attracted great attention of scientists. The best known and most frequently cited globalization indexes, which bring together different areas of indicators of globalization is the globalization index Kearney and Dreher (KOF) globalization index.

Through globalization leads to the internationali-

Author's address: Aleksandra Vidović, Pan-European University “APERION", College od Management Modern, Banja Luka, Pere Krece 13, Bosnia and Herzegovina

Paper received: 23.07.2015.

Paper accepted: 08.09.2015. zation of enterprises, form internationalization at the end of the last century were the mergers and acquisitions strategy.

Today the question is a fusion of the company one of the areas of finance, which attracts the attention of both the public and financial experts and managers. Oblast Fusion includes a set of important and specific activities that affect many areas of business life.

The transformation process of integration and fusion power companies appeared as a significant integral component change.

We are witnessing the integration in accordance with the long-term development of the market, initially in the state framework, and today in the wider local and global scale, promote the inevitable process of external growth of companies in the world.

Given that allow fundamental changes in all structures and mergers are now the dominant strategy of the company for its own positioning in anticipation of the new challenges of the 21 st century. [7]

The disappearance of barriers of distance, specializing in key capabilities and geographic dispersion of business activities are some of the aspects that characterize contemporary global companies that dominate international markets. [6]

Internationalization becomes a condition of survival companies, regardless of size or country of origin. The above fact is particularly evident in some industries such as automotive, pharmaceutical, airline transport, industry, etc. The internationalization of economic activity has made transnational competition. [1] 


\section{ENTERPRISE}

The company is an independent, economic, technical, market - financial and social entities in the private and public property, which produces goods and services for the market, with the use of human and material resources, and bear in this business risk in order to maximize profits and other economic and social objectives. The reasons for existence, the company exists because the costs of routing resources of the company are lower than the cost of using the market mechanism. In addition, important reasons for the existence of the company are reflected in the benefits of joint efforts of the company in relation to the work of individuals:

- The division of labor and specialization of employees;

- The greater use of technology;

- Easier management of the external environment;

- The reduction of transaction costs and

- Greater incentives and better control. [3]

There is a division between small and mediumsized enterprises. Small businesses (Eng. Small business enterprises) exist in almost all economic fields. These companies, according to economic parameters, have a small volume of business, small capital invested and a small number of employees. It structurally fits into the economic space that did not cover the large and medium-sized enterprises and carry out the tasks for which you are not interested, or which are not profitable for larger companies.

Company's small business increase the degree and extent of the use of new resources of an economy with a high degree of flexibility and adaptability to new market and other conditions. Small companies, as a rule, establish an individual entrepreneur, who is also the owner and manager of the company. He alone makes all decisions related to the business and bears the risk of doing business. Most countries take certain factors into account when talking about the difference between small and large enterprises and the state:

- Total annual income of sales,

- Number of employees

- Shareholders' suspicion

- The total value of the company.

Medium-sized enterprises are at the transition between small and large. Medium-sized enterprises have certain similarities with both small and large companies. The advantage of medium-sized companies relative to large in greater flexibility and relative to market and technology changes. This is especially true in industries where speed and ability to adapt is an essential condition of business flexibility. The division of labor and cooperation have been considerably deve- loped in these types of companies. Medium-sized enterprises are characterized by a high degree of specialization relatively. Affairs and completeness of work and technological processes. The high degree of specialization of business functions in medium-sized companies leads to an increase in the overall flexibility of the company.

\section{DEFINITION OF ACQUISITION AND FUSION}

Mergers and acquisitions occur when companies merge (fusion) or take control of (acquisition) of the whole or part of the business of other companies.

\section{Fusion}

In literature, we find the definition of fusion which is generally boil down to the fact that mergers (fusion, merging) as a strategy, as well as methods of radical change in which the two companies negotiated integrate, or its activities, the relatively equal basis. Such fusion is less, since it is always one side of the dominant. Gaughan said that the merger of two corporations whose combination, where one survives, and annexed it ceases to exist. The company that carried out the merger take over the assets and liabilities of another company. As a result of the merger created a new company. Fusion can be described by the legal and economic aspects.

\section{(1) According to the legal aspect}

Legal transaction structure, which, depending on the nature of the transaction can take many forms. Fusion in the literature and in practice also called merger and a combination of two or more companies, where all but one legally cease to exist, and the combined organization continues operations under the original name of the company that survived or new name.

There are three types of fusion:

- Statutory fusion - where activator of the firm takes over the assets and liabilities of the target company in accordance with the statutes of the state in which the combined company will be incorporated.

- Subsidiary fusion - this merger, the two companies created when the target company becomes a subsidiary of the parent company.

- Short form fusion - occurs in situations where the parent company, the primary shareholder of departments and merger does not require the approval of the shareholders of the parent company.

\section{(2) According to the economic aspect}

From the economic point of fusion can be classified as horizontal, vertical or conglomerate merger. How will the merger be classified depending on whether the company in fusion (merger) within the same industry or not and of their position in the corporate 
value chain. Therefore, the following different types of fusion.

- Horizontal Fusion - arises between two companies that are in the same industry.

- Conglomerated fusion - occurs when a company buys companies in unrelated industries.

- Vertical mergers - are those in which the two companies participating in the various stages of the manufacturing value chain. In the context of the value chain, a vertical merger is one where companies that do not have operations in every major segment of the value chain are selected to integrate with suppliers backwards or forwards with the distributor.

- Fusion of equal - is always when we have that the participant's mergers comparable in size, competitive position, profitability and market capitalization.

\section{Acquisition}

The acquisition (merger) is a strategy in which a company buys a controlling stake in the company, making it the company organizational unit. [5]

A company that seeks to take over or merge with another company called the acquisition Company. In the broadest sense means any acquisition of the company acquiring another company or significant stake in the equity of another company by the so-called. solicitation companies, regardless of whether this acquisition with the purchase of property or ownership share of acquired companies or merging proprietary interest.

\section{GROWTH AND DEVELOPMENT COMPANIES}

The priority of each society should be a long-term sustainable and stable growth. What is the best way to achieve this objective is to be determined through a variety of instruments of economic policy, one of them is the use of an optimal combination of domestic and foreign investment as well as public investments.

However, if we observe the course of history can be seen that there are events which fundamentally changed the world order. So at the time of the French Revolution, Europe is faced with the changes that have been thoroughly enforced the former attitude, leading to the rapid development of new ideas.

Frequent changes in the financial markets today are more significant factor than ever. Many organizations are doing what they have always done, are no longer observed.

What used to work, no longer works. Such firms were profitable, and today they are in the red. Changes have to be made if the organization wants to adapt to market changes.
Interpretation of $\mathrm{M} \& \mathrm{~A}$ activity, forecasting and structuring transactions depends on the presence triggers of economic turbulence in the business environment. A list of these initiators includes:

- Deregulation;

- Demographic change.

- Trade liberalization;

- Technological changes;

- Geopolitical changes;

- Innovations in financial markets; [2]

\section{CONCLUSION}

Mergers and acquisitions in line with long-term development of the market, to start in the country borders, then on a regional scale, promoting themselves as an inevitable process of external growth for many companies in the world. Today it is the main lever for achieving growth and synergies of large and strong companies in achieving strategic goals for the future. [4]

Mergers and acquisitions represent methods of enterprise transformation in a global environment that enable companies to adjust to opportunities from the environment and to better position themselves in order to achieve greater value for their stakeholders. The definition of what constitutes an acquisition requires defining the acquisition strategy where one the company bought control package or a share of $100 \%$ in another company, making its subsidiary.

On the basis of practical examples of the implementation of strategies mergers and acquisitions, we conclude that there is little real fusion formed on an equal basis, the merger of equals and that each fusion can be viewed from the angle of acquisition covert intentions.

\section{REFERENCES}

[1] Baković, T, Lazibat, T, \& Lulić, L. (2006). Međunarodna spajanja i akvizicije u hrvatskoj godspodarskoj praksi. Ekonomski pregled, 57(1-2). Retrieved 06 26, 2015.

[2] Bruner, R. Applied Mergers and Acquistisitions. John Wiley and Sons, 2004.

[3] Coase, R. The Nature of the Firm, 1937.

[4] DePamphils, D. Mergers Acquistisitions and other Restructuring Activities an Integrated Approach to process, tools casses and solutions. Elsevier.

[5] Hitt, M, Ireland, R, \& Hoskisson, R. Strategic Competetivness and Globalisation. Tomson, 2003.

[6] Kolaković, M, \& Lazibat, T. Međunarodno poslovanje u uvjetima globalizacije. Zagreb: Sinergija, 2004. 
[7] Martić, D. Fuzija preduzeća- utvrđivanje koeficijenta zamene akcija. Ekonomski horizonti, 85-96, 2009, 1 11 .
[8] Suzić, N. Globalizacija. Banja Luka: TT Centar, 2001.

\section{SUMMARY}

\section{RAST I RAZVOJ PREDUZEĆA U FUNKCIJI FUZIJE I AKVIZICIJE}

U radu autor afirmiše potrebu: akvizicije i fuzije kao elementa rasta i razvoja preduzeća. U radu se daje kritički prikaz priloga na zadatu temu. Osnovni cilj rada je utvrditi značaj strategijskih aspekata fuzije i akvizicije kao strategija rasta i razvoja preduzeća. Ove dvije strategije omogućavaju preduzećima da se prilagode poslovanju $i$ ostvare veće finansijske efekte $u$ današnjim uslovima poslovanja kakve zahtijeva globalizacija.

Ključne riječi: preduzeće, rast, razvoj, akvizicija, fuzija 